\title{
Adolescent Refugees Challenging School and Education-A Multi-Level Analysis of the Austrian School System
}

\author{
Martin Kölbel \\ Hoffeld, Aspang, Austria \\ Email: Koelbel_Martin@gmx.at
}

How to cite this paper: Kölbel, M. (2022). Adolescent Refugees Challenging School and Education-A Multi-Level Analysis of the Austrian School System. Creative Education, 13, 38-54.

https://doi.org/10.4236/ce.2022.131003

Received: November 10, 2021

Accepted: January 11, 2022

Published: January 14, 2022

Copyright (อ 2022 by author(s) and Scientific Research Publishing Inc. This work is licensed under the Creative Commons Attribution International License (CC BY 4.0).

http://creativecommons.org/licenses/by/4.0/

\section{(c) (i) Open Access}

\begin{abstract}
Within educational systems, discussions have long been held about whether and to what extent refugees and displaced people can be integrated. Due to rare insights, this paper discusses how far school authorities as well as participants handle and adapt to more heterogeneous student groups. Study participants consist of national and federal school authorities, principals, teachers, local students and refugees (both parents and children) having either fled due to the Syrian war or due to fear of facing Afghan persecution. For this study, interviews with the aforementioned participants, being allocated to different levels (i.e. micro-, meso-, or macro-level) of the Austrian school system, have been conducted to ensure variety and transparency of data. The investigation showed that notions of what are the right decisions leading to the right measurements in relation to the integration of adolescent refugees seem to vary depending on individual protagonists' level of work within the Austrian school. While decisions from both school authorities as well as educators are comprehensible for those working within the same level, decisions taken on another (usually higher) level, are frequently regarded as unsupportive or even convey a negative image causing disappointment, frustration and display lacking interconnectedness between individual levels.
\end{abstract}

\section{Keywords}

Adolescent Refugees, Inclusion, Austrian School System, Heterogeneous Classes, Multi-Level Analysis, Lacking Interconnectedness

\section{Introduction}

"Nobody should be left behind but the real test is yet to come, namely the implementation. We, therefore, need help from everywhere and everybody." (Ban, 
2015)

By using these words, the former UN Secretary General Ban Ki-moon appealed to his audience at the summit for sustainable development in New York to combat the cause of flight as well as persecution on our planet. Both notions-flight and persecution-seem to accompany mankind since the beginning of time and are these days emotionally charged as never before. Also within Austrian news agencies, reports related to flight and persecution are shown and topics linked to flight and persecution, as for example the arrival of adolescent refugees within the Austrian school system, are covered more and more frequently.

While the majority of refugees (some of them might even be regarded as migrants) started their journey from war-torn countries such as Syria and Afghanistan (Austrian Ministry of Interior, 2021) together with their parents, an increasing number (nine percent) among refugees arrives in Austria without their parents or any relative at all, thus being referred to as "unaccompanied minor refugees" (Interior Ministry Austria, 2021). Despite differences in terms of origin, flight history, first and second language skills and curricular education, these children and adolescents are regarded as students at a compulsory education age (Blossfeld et al., 2016; Burrmann \& Mutz, 2016).

Although Austria and, consequently also the Austrian education sector, have witnessed and experienced flight and migration also in former times (e.g. riots in Hungary, war in Jugoslavia) which caused an increasing heterogeneity of Austrian classrooms, questions of how to integrate refugee children and also how to overcome potential barriers in the course of the integration processes among different ethnicities have not been dealt with. Despite research being carried out on a positive integration of various ethnical and social groups both at school as well as in clubs (Teubert, 2009; Kleindienst-Cachay, Cachay, \& Bahlke, 2012) including recommendations for educational authorities and teachers from the United Nations (2006), the Pope ("Erga migrantes caritas Christi") or Austria's Education Ministry (BMBF, 2015, 2016) scientifically proven studies are hitherto lacking.

Within national and international educational systems, discussions have always been held about whether and to what extent refugees and displaced people can be integrated. Physical education and sports appear to be on top of the hierarchy among the subjects which have a high potential of integrating potentially vulnerable (i.e. handicapped) groups (Australian Sports Commission, 2006; Tiemann, 2013; Tiemann, 2015a). Since the majority of the above mentioned studies focus merely on "disability sport" (Black \& Stevenson, 2012) including almost exclusively handicapped groups of students, the author aims at a broader discussion; hence this paper discusses whether and to what extent individual levels of the Austrian education system, and more specifically the protagonists working on each the different levels, contribute to an integration of juvenile refugees and aims at answering the subsequent research question:

(How) Do authorities as well as participants of the Austrian school system 
handle and adapt to new challenges caused by more heterogeneous student groups (due to the latest migration and flight movements)?

First, the study design, including participants, analysis tools and background information are presented. Subsequently, the results of the analysis among school authorities as well as representatives within the Austrian school system focusing strongly on conducted interview files will be presented. After that a critical discussion of current strategies and approaches on how to integrate refugees, migrants or displaced people in Austrian classes is presented. In conclusion, further measurements, goals and possible challenges are discussed.

\section{Materials and Methods}

\subsection{Study Design}

Research on (adolescent) refugees frequently leads to discussions about the notion of "de-segregation" (Booth, 2008, 2012), integration as well as the "qualitatively advanced concept" (Feyerer, 2012: p. 4) of it-inclusion. The majority of research being conducted in the context of refugee and migration research focuses on "bottom-up" approaches (Booth, 2008, 2012; Hinz, 2013) analysing the corresponding study question merely from one perspective, namely from the perspective of refugees and their social surroundings. Taking this aspect into consideration ultimately leads to the question whether analysis can also be carried out from another perspective, a "top-down" perspective, in which research focuses on school authorities and their influence on the hierarchical structures below. The perception of the hierarchical Austrian school system in connection with an analysis of inclusive structures related to adolescent refugees led to the question of what remains between the two spheres "bottom-up" and "top-down".

In order to assess whether or not adolescent refugees face inclusive structures as well as inclusive teaching concepts within the Austrian school system, which welcome heterogeneity instead of regarding it as an obstacle, this study focuses on evaluating inclusive perceptions on different levels. In practice, reactions and responses towards integrating adolescent refugees shall be analysed from three different perspectives-the micro-, the meso- and the macro-level of the Austrian school system.

As can be seen from Picture 1, the Austrian school system is separated into three areas of research (micro-, meso- and macro-level); each of the areas is directly linked to the hierarchical level above and indirectly influenced by subordinate levels. Most importantly, the model should not be regarded as a one-way street in which influence is merely exercised over the adjacent levels (either from top to bottom or vice versa); however, the trichotomy of cause-effect relationship also helped to analyse and consequently present possible outcomes transparently.

Analysis of refugee movements caused by the refugee crisis in Europe since 2015 (e.g. war in Syria, persecution of minorities in Afghanistan, etc.) and the increasing heterogeneity in Austrian classrooms cannot be conducted merely on 


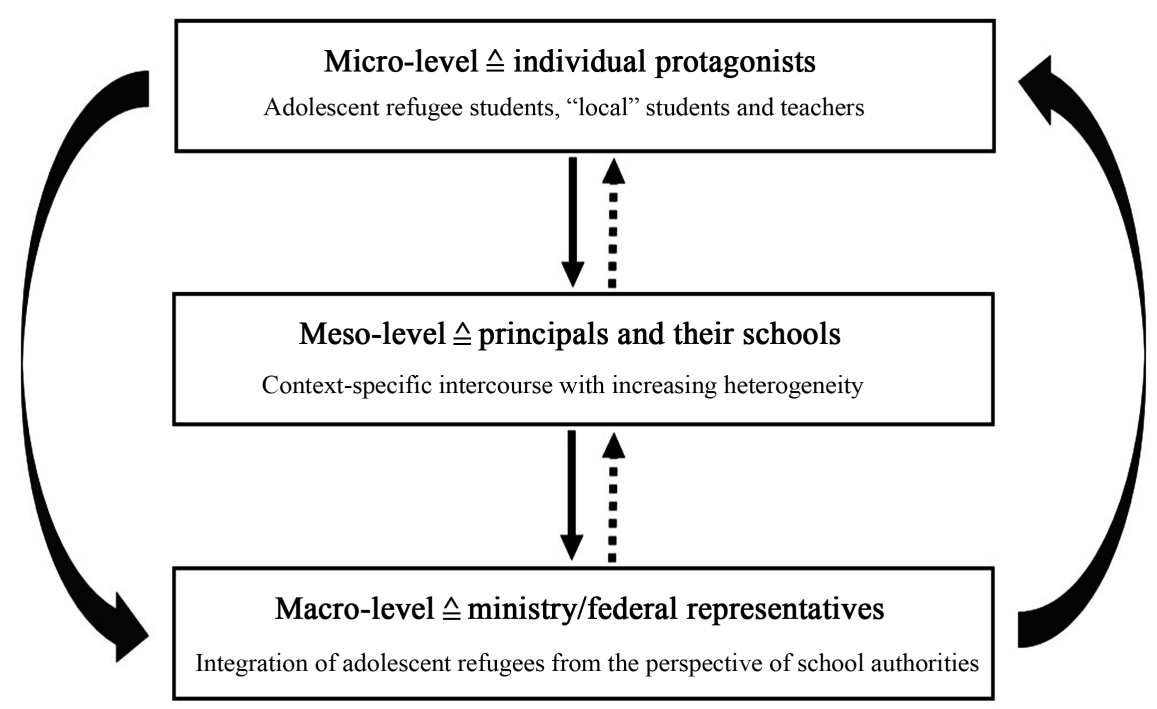

Picture 1. Trichotomy of cause-effect relationship.

the level of the education ministry, on the level of individual schools or even on a personal level. To ensure greater variety of data, all three levels have to be taken into consideration; therefore, this study focuses on inclusive structures on a multipolar tier to guarantee a differentiated perspective of school authorities, individual schools as well as classes being composed of adolescent refugees.

\subsection{Participants}

In order to analyse the Austrian school structure in relation to adolescent refugees, a concept has been established which after the implementation and analysis of interview files enables a holistic insight into the topic of interest. Due to the overlapping hierarchical structure of Austria's school system this procedure is regarded as essential. Despite the availability of research work focusing on individual parts in certain areas of the school system (Altrichter \& Merki, 2010), the majority of research either takes student focused topics into consideration (Breidenstein, 2004, 2006; De Boer, 2006) or focuses on didactics and difficulties related to that (Combe \& Kolbe, 2004; Breidenstein, 2008). For the prevalent study and its corresponding research question, this approach is considered as too short sighted.

While the majority of refugees (some of them might even be regarded as migrants) started their journey from war-torn countries such as Syria and Afghanistan (Austrian Ministry of Interior, 2021) together with their parents, an increasing number (nine percent) among refugees arrives in Austria without their parents or any relative at all, thus being referred to as "unaccompanied minor refugees" (Interior Ministry Austria, 2021). Many of the newly arrived migrants are education-wise regarded as "losers" (Gresch \& Becker, 2010). Although differences in terms of education between refugees and locals become less and less with the passing of time (Berngruber, Pötter, \& Prein, 2012), it is nevertheless a matter of fact that "integration through education is the most important educa- 
tional measure throughout history" (Blossfeld et al., 2016: p. 15).

With reference to the above mentioned quotation, representatives of all levels of the Austrian school system have been interviewed to ensure greatest possible variability of insights into intercourse with adolescent refugees. Due to rare insights, which are sometimes even referred to as "blind spots" (Behrensen \& Westphal, 2009), subsequent representatives of the Austrian school system (Table 1) have been interviewed:

\subsection{Measurements}

As can be seen in Table 1, interviewees were selected with reference to the hierarchical Austrian school system. Representing the highest level of the Austrian school system (i.e. macro-level), representatives of the education ministry have been interviewed; furthermore, on a federal level, supervisors for inclusive education as well as physical education have been interviewed. The latter has been chosen, because physical education and sports appear to be on top of the hierarchy among the subjects which have a high potential of integrating potentially vulnerable (i.e. handicapped) groups (Australian Sports Commission, 2006; Radke \& Tiemann, 2014; Tiemann, 2015b). The subjacent level consisted of school principals (i.e. meso-level) and teachers at different Austrian schools both of whom being experienced in handling or teaching adolescent refugees and, above that, being aware of potential difficulties. On the micro-level, interviews

Table 1. Interviewees ${ }^{1}$.

\begin{tabular}{cc}
\hline Hierarchical level & Representative \\
\hline Macro-Level & Ministry of Education-refugee coordinator \\
Macro Level & Federal supervisor for inclusive education \\
Macro Level & Federal supervisor for physical education \\
Meso-Level & Principal 1 \\
Meso-Level & Principal 2 \\
Micro-Level & Teacher 1 \\
Micro-Level & Teacher 2 \\
Micro-Level & Teacher 3 \\
Micro-Level & Local student \\
Micro-Level & Adolescent refugee 1 \\
Micro-Level & Adolescent refugee 2 \\
Micro-Level & Adolescent refugee 3 \\
Micro-Level & Refugee parent 1 \\
Micro-Level & Refugee parent 2 \\
\hline
\end{tabular}

${ }^{1}$ Next to interviews a group discussion, in which three protagonists of the Austrian educational system have participated, has been conducted. 
with local students as well as adolescent refugees have been held; furthermore, also interviews with two parents of adolescent refugees ${ }^{2}$ attending the Austrian school system could be conducted.

All aforementioned interviews were conducted by the author. While the majority of the interviews could be held either in German or English, one interview with a refugee parent required the help of an Arab translator due to language barriers.

Being aware of the high vulnerability of the study participants-especially adolescent refugee and refugee parents-a detailed description of the study design has been sent to the ethical review commission of the University of Vienna in advance of the study. It was only after the positive feedback of the ethics commission that the study could commence by briefing all interviewees on the purpose of the project and the procedure of the interviews.

\subsection{Data Analysis}

"All actions [...] as well as all statements in interviews are influenced by the structures and [social] processes of the environment, which surround a person" (Froschauer \& Lueger, 2003: p. 12). This citation proves and legitimizes interviews in empirical social research, as actions of a person are not influenced by independence or autonomy; instead actions are always embedded in the specific situational context. Just as society influences individuals, individual people and their corresponding actions influence society equally (Maed, 1978). Taking this mutual influence of individuals and society into consideration, the interview as a means of inquiry seems to be highly effective.

In total, 14 interviews and one group discussion $(\mathrm{N}=15)$ have been conducted over the course of 10 months. The data processing from the interview files have been conducted using MAXQDA 2018. In order to ensure highest possible data validation as well as replicability (Flick, 2007; Lüders, 2005; Thiele, 2005) another scientific researcher, had a look at the interview sequences and added his remarks to the existing field reports. Comprehensible and overlapping remarks for each of the files have then also been transferred into a word file.

For an analysis of the data the researcher applied content analysis (Mayring, 2017) in which a code is being applied to almost all of the relevant text passages. The search for patterns and similarities between individual codes revealed broader themes. This can be done through either using terms from already existing literature on the field of study or through so called in-vivo-coding by using terms for concepts showing up in the data itself which is also applied "in educational ethnographies with youth" (Saldana, 2016: p. 106).

Despite the fact that individual interviewees did not necessarily mention the same thing, different discussions could be summarized as different aspects of the same thing, as can be seen in the subsequent table (Table 2).

${ }^{2}$ However, the interviews with refugee parents have not been further analyzed in the course of this manuscript. 
Table 2. Data extract and equivalent code.

\begin{tabular}{ll}
\hline \multicolumn{1}{c}{ Data extract } & \multicolumn{1}{c}{ Coded theme } \\
\hline $\begin{array}{l}\text { There are } 25 \text { children in a class and you need } \\
\text { more or less } 21 \text { different tasks for them. }\end{array}$ & 1) Heterogeneity in the classroom \\
$\begin{array}{ll}\text { Especially because of poor communicative skills. } & \text { 2) Language faculty } \\
\text { I do have difficulties in German and math, } & \\
\text { as I was used to the Arab language. } & \text { Language faculty }\end{array}$ \\
\hline
\end{tabular}

In order to ensure high sensitivity towards adolescent refugees and, simultaneously, dismiss a "one-size fits all reasoning" (Tiemann, 2015b: p. 55) in Austrian school settings, the main themes (i.e. major categories) derived from the interviews will be presented in the next section.

\section{Results}

The results of this study are presented on the basis of four main themes deducted from a profound analysis of interview data: 1) flight background; 2) heterogeneity in the classroom; 3) language faculty; 4) legal conflicts. A selection of the most prominent quotations should emphasize the results; crucially, statements of participants should not be regarded as opinions of individuals, but as a comprehensive frame of common understanding (Dahlin-Ivanoff \& Holmgren 2017).

\subsection{Flight Background}

This category summarizes those aspects which are related to adolescent refugees' experiences before or during their flight to Austria. In some cases, juveniles and their parents had to flee from their home (town) before actually leaving their country with or even without their family; hence these people are referred to as "internally displaced people" and have experienced difficult times before their actual flight:

Regretfully, we have changed school several times due to our flight. We did not even have school uniforms any longer [...]. We also have moved houses, changed schools-six times within half a year-that was really difficult. (RSI; $22)^{3}$.

On a psycho-social basis every experience related to flight coins the individual protagonists. In the same way, numerous friendships which are influenced and sometimes even fade due to flight affect adolescent refugees:

I thought that friends are nice. But then we had to flee, which meant I had to leave my friends back. But thank God, I still do have one friend I went to kin-

\footnotetext{
${ }^{3}$ In order to ensure anonymity among the participants as well as transparency a three-tier system has been applied; while the first letter indicates the function of the person in the school system $(\mathrm{M}=$ Ministry, $\mathrm{P}=$ Principal, $\mathrm{T}$ = Teacher, $\mathrm{S}=$ Local student; $\mathrm{RS}$ = Refugee student), the first number indicates the specific refugee student, teacher, principal, etc. (i.e. 1, 2 or 3), the second number indicates the line number of the transcript, this quote can be encountered. The conducted group discussion with representatives of the federal education ministry is simply called "group discussion".
} 
dergarten with. Her mum was a friend of my mum. And when we fled our country, we surprisingly met again-that is so funny. We still stay in contact. (RS1; 26)

In contrast, other descriptions ensure insight into the challenges and difficulties which people had to undergo during their flight. Before residence in a safe target country could be achieved, families had to surpass certain obstacles. In some cases the family had to separate during flight:

At first we were fleeing together to Turkey, where my father hoped to find work. Unfortunately, he did not find work in Turkey, that is why we wanted to move to Europe. However, we did not have any money. Next, we travelled by boat to Italy, but we shipwrecked. That is why we came to Greece, where we stayed for more than four months. Since we ran out of money, my father sent me together with one of his friends to Sweden where we do also have relatives. So I travelled to $S$ weden with my father's friend. In the end, it took me one year and five months to see my family again in Austria. (RS2; 6)

Children and adolescents with flight experiences, the separation of close family members and subsequent isolation can trigger psychological problems leading to PTBS (i.e. post-traumatic stress disorder) and traumata (Inal, 2017). Likewise, Metzner \& Mogk (2016) show the numerous consequences of traumatic experiences made by adolescent refugees, while Becker \& Weyermann (2006) have taken up the concept of "sequential traumatisation" (Keilson, 1979) and adapted it for refugees. Especially educational institutions should therefore be aware of the causality between individual flight background and possibly related psychological strain.

\subsection{Heterogeneity in the Class Room}

Similar to Austrian (local) students, juvenile refugees show great discrepancies in terms of race, religion, language, educational experiences, etc. Nevertheless, all these differences and barriers have to be broken down inside the classroom to ensure cooperation and fruitful learning. The different manifestations of heterogeneity influence Austrian schools and education of individual classes in different manners. At first sight, differences could be spotted and linked to specific countries of origin:

In sum, the system has changed, because classroom settings have changed: The composition of classes, the diversity of classes, diversity of cultures-also how different cultures and religious beliefs are handled in a classroom. We do have 26 different nationalities which have become more because of the flight movement of 2015. (Group discussion; 42-51)

[...] You do not only have Afghan, but also Syrian students. Sometimes you have Afghans who were raised in Iran. So it is completely diverse. (T2; 4)

In comparison, other forms of heterogeneity, which surpass a classification according to nationalities, can be spotted. Also these manifestations have to be taken into consideration when talking about adolescent refugees in school set- 
ting; ideally, different manifestations are thought through in advance to minimize the challenges for teachers:

Adolescent refugees can be differentiated into those who are highly motivated, highly educated and already have experienced education. These are the ones who learn German quickly, pass school leaving exams and even attend higher schools or graduate from university. On the other hand, there is the group which might not even have experienced kindergarten, have never attended school. Many of them have fled for several years and, thus, never experienced what school is like. Often, their parents have experienced education neither. This group of students is the real challenge. (Group discussion; 67)

The different approaches to and experiences with education or educational institutions have already been mentioned. However, also the challenges of individual teachers who have to handle heterogeneous experiences in terms of education within classroom settings should be mentioned:

The next major problem concerns the individual background; for example, the family of one student runs a shoemaker's all of them having never attended school, while others have attended a private school in, for example Baghdad. The latter is extraordinary in math and many other subjects, while the former has severe difficulties. (T2; 4$)$

One major problem was the majority of those students who have never attended school and, thus, do not have the slightest sense of punctuality, reliability, or the like. (T2; 40)

These descriptions of various educational experiences show the increasing diversity of Austrian classrooms. Also differences within certain subjects can be spotted, as the subsequent narrative of a teacher proves:

I do have an extraordinary student from Serbia being in Austria for two years now. Her level of German is B1, she should already attend the next class in math, but she speaks English like an elementary student, because she has never studied a second language (except German). She has gained extraordinary skills in certain subjects enabling her to advance already to the next class. However, I do also have students who are at the same age (13 years), but they are on an educational level of elementary school. I cannot put all of these students into the same pot and hope that they advance equally at the same time. (T3; 48)

Due to these differences which can also be identified at different schools, individual strategies on how to handle heterogeneity can be witnessed. Different schools seem to develop individual strategies in order to meet the challenge of fluctuating heterogeneous student groups-one of these solutions shall be mentioned below:

In the previous term, I had to teach two 15-year old refugees, who according to their age should be in the fourth form; however, in English they had to attend ${ }^{4}$ In Austria, foreign students having severe difficulties with the German language are granted the status of an "extraordinary student" for a maximum of two years. This should ensure that these students can focus on learning the target language (German) without being graded at school (cf. Section 4.4). 
the first form since their level of English was rather basic. We explained the first form students the situation so that they did not laugh at them, and that was not a problem for both refugees as well as regular students. (T3; 52)

In addition, to the already diverse category "heterogeneity in the classroom", another aspect of this manifestation has to be taken into consideration, which is mentioned by a representative of the educational ministry (M; 66): "Among the group of juvenile refugees are also handicapped students who due to this reason need special attention".

All these diverse forms of heterogeneity highlight the challenges which Austrian school system and all involved people have to face. Due to increasing numbers of adolescent refugees, these challenges do not become less demanding and thus require special caution.

\subsection{Language Faculty}

Language and communicative skills of adolescent refugees attending Austrian schools are prevalent in this category. Especially curriculum-based teaching of newly arriving students has to be critically viewed, as the following statement shows:

It is hypothetical to assume that they (i.e. adolescent refugees) arrive at elementary school age and start learning our mother tongue while everything else can be taught later on. This would work. But juvenile refugees arriving at the age of 13 or 14, attending our school system for two years before being dismissed to start an apprenticeship where nobody teaches them German for free have to be handled differently. This does not work. Many of them do only have two to three years of elementary education before leaving school. That's not enough. (T3; 42)

They (i.e. adolescent refugees) cannot even say. "Where is the toilet?" Nothing, he cannot even express himself. We were simply left alone. (P2; 32)

How should I teach anybody a word, if he/she does not even know the alphabet? $(T 3 ; 60)$

As these quotations show, language faculty remains definitely an obstacle when accessing education or educational institutions. Both adolescent refugees as well as their parents face this problem as both frequently lack basic language knowledge of the target county. This, is return, conveys the feeling of being left alone among teachers who long for more support. On the contrary, also individual fate of juvenile refugees and their parents should not be disregarded. The majority of them had to flee and save their life or the lives of family members which explains that language acquisition was not prioritised:

Children and adolescents at flight are children without any knowledge of the corresponding mother tongue. This means that those children can be smart, but are simply not able to follow education. I have never met any Syrian, Afghan, Iraqi or Somalian kid who already at home could prepare for the language of the target country. $(M ; 40)$

After the illustration of the seemingly opposing poles, a gap between communicative demands and reality can be recognized. Hitherto, the question arises 
how people communicate at school if the language barrier seems to be too challenging. A glimpse at Austrian schools and class room settings shows that individuals overcome this problem differently. While one teacher relies on a common foreign language between her local and newly arrived students: "I do talk English in my classes, because the foreign students do not understand German." (L1; 4), communication between locals and foreign students sometimes seems to work quite smoothly especially in sports classes, as the following quote highlights:

All participants moved to the playing field to sort out problems. We, the other students, helped to explain the rules. It has never happened that all of us were waiting for 15 minutes or more until each and every word has been explained. It has been explained again, or demonstrated - this has not been a problem at all. Those students have spoken the language quite well and they have even understood much more. $(S ; 78)$

With reference to the language education of adolescent refugees, it might be recommendable to get rid of traditional ways of teaching in which only the teacher is seen as a resource of knowledge, What is more, "the first German teacher, it the class mate; as Austrian students usually do not speak Arab, they have to communicate in German or a shared common language" (M; 46). In addition, "not only teachers of German or English are language teachers for the newly arriving students, but every teacher at school [...]." (M; 98)

\subsection{Legal Conflicts}

Next to the aforementioned challenges through new migration movements, which frequently cause altering perception of commonplace and even cause "perceptions of otherness" (Benn \& Pfister, 2013) within the Austrian school system, the legal status of the newly arriving students has to be clarified. In Austria, many of the juvenile refugees are categorized by school authorities and also principals as extraordinary students which is defined as follows:

Who is defined an extraordinary student at school? Not those who are extraordinarily smart, but extraordinary status is granted for those who have language difficulties and thus, might be incapable of following traditional teaching. $(M ; 40)$

This special status should facilitate the access to and entrance to the Austrian school system among adolescent refugees; furthermore, also teachers do not have to face pressure of grading those children who are incapable of expressing themselves properly. This status aims at not grading the children for two years, as they would fail classes due to a lack of language knowledge. However, this status is also linked to language learning aspirations and limited to, as already mentioned, a maximum of two school terms.

The idea of granting juvenile refugees a special status due to lacking language skills being therefore incapable of following teaching, is comprehensible and proves a powerful tool for facilitating integration. However, taking into consideration that many of the newly arriving children have not yet finished compul- 
sory education after two years, the following critique can be reasoned: "There is neither any idea of how to grade those kids after two years, nor can those children be taught in accordance with regular students." (T3, 44)

Again, individual flight and education biographies of adolescent refugees (cf. 4.1) affect and even exacerbate the situation even more. Consequently, this again leads to an even increasing number of heterogeneous children in classes which teachers and principals have to solve individually:

Those children aged 13, do not have experienced seven years of school education, they have experienced two years of flight and witnessed flight camps in Turkey or elsewhere. This means, I cannot teach and grade him according to a 7th form. [...] This has to be changed. (T3; 44)

However, not only individual teachers or principals are aware of this shortcoming, also representatives of the education ministry are aware of the extraordinary status and corresponding problems linked to students who enter the education system late:

We have long been fighting for a voluntary 10th school term ${ }^{5}$ especially for extraordinary students. Especially after 2015, when juvenile refugees attended school only at the age of 13 or 14, many of those could simply not follow teaching and education due to language barriers. Nevertheless, many of them had to leave school system without any future perspective at the job market. It took quite a long time until legal authorities have reacted and adapted the system. (Group discussion; 55-59)

The above addressed issue of releasing juvenile refugees without any prospects, after having experienced only two years of education, does only show one side of the coin. Likewise, refugees attending Austrian schools from an early age cause challenges in an inflexible system:

I have to dare to catch up on math, because they do not know how a rectangle looks like, or how to calculate the face of a square. I have to dare to say that one student in German advances already to the next class, while he remains in math in the same class and attends a beginner class in English. This is a totally different way of thinking, since those kids have not experienced education in a way our kids have had. (T3; 46)

For the future, many aspects have to be changed especially on a legal level, ensuring that teachers, principals as well as school authorities do not have to act in a legally speaking grey area. Ideally, teachers could focus on their profession-teaching and educating children and teenagers.

\section{Discussion}

The purpose of the current study was to evaluate whether or not school authorities as well as local school settings (i.e. principals and teachers) adapt and handle heterogeneously increasing student groups focusing especially on the latest flight and migration movements to Austria. As prevalent research on increasing num-

${ }^{5}$ In Austria, compulsory school ends after nine years at school. "Regular" students attend senior year at the age of 15 . 
bers of refugee students in educational systems is still at the beginning, the study aims at a contribution to a more comprehensive notion of adolescent refugees on both a national and an international level.

As far as the research question is related, results provide evidence that either group of students (refugees as well as locals), their teachers and, in addition, also principals adapt; however, it is crucial to consider the individual flight background of adolescent refugees as this might cause impairment on different levels embracing for example individual educational backgrounds, acquired language skills, and most importantly also the psychological well-being of juvenile refugee students. Similarly to the (core) category adaptation, another important characteristic has been established through the analysis of the Austrian school system-the lacking interconnectedness between individual levels.

Interestingly enough, notions of what are the right decisions leading to the right measurements in relation to the integration of adolescent refugees seem to vary depending on individual protagonists' level of work within the Austrian school system. For example, concepts and strategies chosen by school authorities on a macro-level (i.e. labelling refugee students as extraordinary students) are not regarded as highly efficient on the micro-level of teachers. At this level, the major difficulty stills seems to be the insufficient language skills which, on the other hand, lead to communicative problems between teachers and newly arrived students. Likewise, principals frequently have the feeling of "being left alone", as they have to take individual decisions for their school (i.e. meso-level) depending on the individual refugee students and their educational background. Contrary to that, both local and refugee students do not regard the aforementioned language barrier as a problem causing severe communicative difficulties within the class room. In sum, decisions taken on individual levels (macro-, meso- and micro-level) might influence each other; however, decisions taken on another (usually higher) level, are frequently regarded as unsupportive or even convey a negative image. Thus, agreement between (protagonists working at) the different levels of the Austrian school system has to be improved by, for example, a better coordination enabling smooth transition of decisions taken on individual levels.

\section{Conclusion}

Adaptations and interrelated challenges arising from the work with an increasing number of adolescent refugees in the Austrian school system can be described among the aforementioned themes of flight background, heterogeneity in the classroom, language faculty and legal conflicts. On an individual teacher level (i.e. micro-level) as well as on a meso-level describing individual school settings, collaboration with juvenile refugees depends strongly on individuality both of teachers and principals. Teachers and their individual perceptions of teaching strongly influence the social setting of their classrooms and their students, which Reich (2012) interprets as a form of "inclusive didactics". 
As can be seen from the above mentioned quotations and interpretations, Austrian school system has changed in different ways and on different levels. Also the pace at which adaptation on different levels has happened, shows the importance of a high flexibility within school organisational structures and especially within the teaching profession. Next to teachers' main goal of conveying knowledge, it is even getting more crucial to "focus on and foster social skills as well as establishing a link between individual subjects and the life of their students" (M, 46). Also Wenning's (2007) social intercourse highlights the significance of accepting increasing diversity among class room settings instead of ignoring them.

Therefore, the work with refugee students at school should depend strongly on collaboration and aim at achieving goals together as a social group; hence, diversity should not be regarded as an obstacle, but as a chance, since "all children and teenagers, irrelevant of their origin, bring along potentials highly needed to foster social education" ( $M, 46)$. However, the way how these potentials can be used inside and outside the classroom depends again on individual teachers and principals who, equipped with their individual pedagogic skills, can influence the newly arrived children positively. "Just as there is no recipe for success in traditional classes, there is also no formula explaining how collaboration between local and refugee students works" (T2, 30). Similar to the diversity of adolescent refugees and their background, the pluralism of teachers and teaching concepts at different school settings might be the goal towards a positive integration of juvenile refugees. In other words, school authorities should rather aim at subjectivity or "subjective theories" (Helmke, 2012) instead of centralized objectives disregarding individuality.

Similarly to individual teacher personalities, heterogeneity at school is also strongly influenced by individual school subjects (Burrmann, 2017; Burrmann \& Mutz, 2016; Krüger \& Gebken, 2017). Conversely, increasing heterogeneity among students also influences individual school subjects, which might lead to subject-specific changes and challenges; thus, on the occasion of rising numbers of juvenile refugees, scientific research should focus on teachers and teacher education enabling them to become acquainted with heterogeneous classroom conditions. The conducted interviews and the presented extracts should contribute to that ambitious goal.

Despite the transformation of a segregation-based towards an inclusive educational Austrian school system, numerous (Austrian) educational institutions as well as teachers long for "concepts, models and strategies which are applicable especially for inclusive education settings and which support acting in those settings" (Tiemann, 2016: p. 1). The demand for concepts focusing on inclusive education which facilitate teaching and, furthermore, provide a guideline for teachers, headmasters or educators in general seems to have risen in recent years. Therefore, it seems highly important to further analyze the Austrian school system following a dual system: While analysis should still be carried out on individual (macro-, meso- and micro-) levels focusing on both individual 
problems and possible solutions to the detected difficulties, research simultaneously has to be conducted on a broader, more general level. On condition that neither perspective-the "individual" as well as the "general"-is neglected, a better coordination enabling smooth transition of decisions seems to be guaranteed.

\section{Conflicts of Interest}

The author declares no conflicts of interest regarding the publication of this paper.

\section{References}

Altrichter, H., \& Merki, K. M. (2010). Handbuch Neue Steuerung im Schulsystem. VS Verlag für Sozialwissenschaften. https://doi.org/10.1007/978-3-531-92245-4

Australian Sports Commission (2006). Sports Ability Activity Cards.

Austrian Ministry of Interior, Bundesministerium Inneres (2021). Asylstatistik Oktober 2021. https://www.bmi.gv.at/301/Statistiken/files/2021/Asylstatistik_Oktober_2021.pdf

Ban, K. M. (2015). Remarks at the World Education Forum on "Sustainable Development Goals and Education". World Education Forum.

https://www.diepresse.com/4829778/vereinte-nationen-wollen-bis-2030-hung er-beseitigen

Becker, D., \& Weyermann, B. (2006). Gender, Konflikttransformation und der psychosoziale Ansatz-Arbeitshilfe. Direktion für Entwicklung und Zusammenarbeit (DEZA) \& Eidg. Departement für auswärtige Angelegenheiten (EDA).

Behrensen, B., \& Westphal, M. (2009). Junge Flüchtlinge-Ein blinder Fleck in der Migrations-und Bildungsforschung. In Krappmann et al. (Eds.), Bildung für junge Flüchtlinge-Ein Menschenrecht. Erfahrungen, Grundlagen und Perspektiven (pp. 45-58). Bertelsmann.

Benn, T., \& Pfister, G. (2013). Meeting Needs of Muslim Girls in School Sport: Case Studies Exploring Cultural and Religious Diversity. European Journal of Sport Science, 13, 567-574. https://doi.org/10.1080/17461391.2012.757808

Berngruber, A., Pötter, U., \& Prein, G. (2012). Bildungsaufstieg oder Bildungsvererbung? Analysen zum Migrationshintergrund. In T. Rauschenbach, \& W. Bien (Eds.), Aufwachsen in Deutschland. AID: A-Der neue DII-Survey (pp. 54-67). Beltz Juventa.

Black, K., \& Stevenson, P. (2012). Information and Advice. The Inclusion Spectrum incorporating STEP. http://www.englandathletics.org/disability-athletics/resources

Blossfeld, H. P. et al. (2016). Integration durch Bildung. Migranten und Flüchtlinge in Deutschland. Waxmann.

https://www.aktionsrat-bildung.de/fileadmin/Dokumente/ARB_Gutachten_Integration _gesamt_mit_Cover.pdf

BMBF (2015). Flüchtlingskinder und-jugendliche an österreichischen Schulen. Beilage zum Rundschreiben 21/2015. https://www.bmb.gv.at/ministerium/rs/2015_21.html

BMBF (2016). Flüchtlingskinder und-jugendliche an österreichischen Schulen. Beilage zum Rundschreiben 15/2016.

Booth, T. (2008). Ein internationaler Blick auf inklusive Bildung: Werte für alle? In A. Hinz, I. Körner, \& U. Niehoff (Eds.), Von der Integration zur Inklusion. Grundlagen-Perspektiven-Praxis (pp. 53-73). Lebenshilfe.

Booth, T. (2012). Der aktuelle "Index for Inclusion" in dritter Auflage. In R. Kersten 
(Ed.), Inklusion und Bildungsgerechtigkeit. Standards und Regeln zur Umsetzung einer inklusiven Schule (pp. 180-204). Beltz.

Breidenstein, G. (2004). Peer Interaktion und Peer-Kultur. In W. Helsper, \& J. Böhme (Eds.), Handbuch der Schulforschung (pp. 921-940). VS Verlag für Sozialwissenschaften. https://doi.org/10.1007/978-3-663-10249-6_38

Breidenstein, G. (2006). Teilnahme am Unterricht. Ethnographische Studien zum Schülerjob. VS Verlag für Sozialwissenschaften.

Breidenstein, G. (2008). Einen neuen Blick auf Unterricht entwickeln. Strategien der Befremdung. In W. Thole, F. Heinzel, P. Cloos, \& S. Köngeter (Eds.), Auf unsicherem Terrain. Ethnographische Forschung im Kontext des Bildungs-und Sozialwesens (pp. 205-215). VS Verlag für Sozialwissenschaften.

Burrmann, U., \& Mutz, M. (2016). Selbstberichtete Angst im Sportunterricht: Eine Analyse unter besonderer Berücksichtigung des Geschlechts und der ethnischen Herkunft. Leipziger Sportwissenschaftliche Beiträge, 57, 95-119.

Burrmann, U. (2017). Integration von geflüchteten Heranwachsenden im und durch (Schul-) Sport? In Deutsche Sportlehrerverband e.V. (DSLV) (Eds.), Sportunterricht Jg (Vol. 6, pp. 163-168). Schorndorf.

Combe, A., \& Kolbe, F. U. (2004). Lehrerprofessionalität: Wissen, Können, Handeln. In W. Helsper, \& J. Böhme (Eds.), Handbuch der Schulforschung (pp. 833-851). VS Verlag für Sozialwissenschaften. https://doi.org/10.1007/978-3-663-10249-6_34

Dahlin-Ivanoff, S., \& Holmgren, K. (2017). Focus Groups. Studentlitteratur.

De Boer, H. (2006). Klassenrat als interaktive Praxis. VS Verlag für Sozialwissenschaften. https://doi.org/10.1007/978-3-531-90436-8

Feyerer, E. (2012). Der Umgang mit besonderen Bedürfnissen im Bildungswesen. Zeitschrift für Inklusion.

https://www.inklusion-online.net/index.php/inklusion-online/article/view/33/33

Flick, U. (2007). Qualitative Sozialforschung: Eine Einführung (3rd ed.). Rohwohlt.

Froschauer, U., \& Lueger, M. (2003). Das Qualitative Interview. WUV-Universitätsverlag.

Gresch, C., \& Becker, M. (2010). Sozial- und leistungsbedingte Disparitäten im Übergangsverhalten bei türkischstämmigen Kindern aus (Spät-)Aussiedlerfamilien. In K. Maaz, J. Baumert, C. Gresch, \& N. McElvany (Eds.), Der Übergang von der Grundschule in die weiterführende Schule (pp. 181-200). BMBF.

Helmke, A. (2012). Unterrichtsqualität und Lehrerprofessionalität-Diagnose, Evaluation und Verbesserung des Unterrichts. Klett-Kallmeyer.

Hinz, A. (2013). Inklusive Inklusion-Von der Unkenntnis zur Unkenntlichkeit!? Kritische Anmerkungen zu einem Jahrzehnt Diskurs über schulische Inklusion in Deutschland. Zeitschrift für Inklusion. https://www.inklusion-online.net/index.php/inklusion-online/article/view/26

Inal, S. (2017). Ich will lernen, aber in meinem Kopf ist immer noch Krieg. Empfehlungen für pädagogische Fachkräfte zum Umgang mit Traumata in der Schule. In: N. McElvany, A. Jungermann, W. Bos, \& H. G. Holtapples (Eds.), Ankommen in der Schule. Chancen und Herausforderungen bei der Integration von Kindern und Jugendlichen mit Fluchterfahrung. Waxmann.

Interior Ministry Austria, Bundesministerium für Inneres (2021). Vorläufige Asystatistik August 2021. http://www.bmi.gv.at/301/Statistiken/start.aspx

Keilson, H. (1979). Sequentielle Traumatisierung bei Kindern. Enke.

Kleindienst-Cachay, C., Cachay, K., \& Bahlke, S. (2012). Inklusion und Integration. Eine empirische Studie zur Integration von Migranten und Migrantinnen im organisierten 
Sport. Hofmann.

Krüger, M., \& Gebken, U. (2017). Sportunterricht für Seiteneinsteiger. In Deutsche Sportlehrerverband e.V. (DSLV) (Eds.), Sportunterricht Jg (Vol. 6, pp. 175-181). Hofmann.

Lüders, C. (2005). Beobachten im Feld und Ethngraphie. In U. Flick, E. von Kardoff, \& I. Steinke (Eds.), Qualitative Forschung. Ein Handbuch (4th ed., pp. 381-401). Rohwolt.

Maed, G. H. (1978). Geist, Identität und Gesellschaft. Suhrkamp.

Mayring, P. (2017). Qualitative Inhaltsanalyse. Grundlage und Techniken. Beltz.

Metzner, F., \& Mogk, C. (2016). Auswirkungen traumatischer Erlebnisse von Flüchtlingskindern auf die Teilhabemöglichkeiten im Alltagsleben und in der Schuele-Erfahrungen aus der Flüchtlingsambulanz für Kinder und Jugendliche am Universitätsklinikum Hamburg -Eppendorf. In G. Markmann, \& C. Osburg (Eds.), Kinder und Jugendliche mit Fluchterfahrung in der Schule. Impulse für die inklusive Praxis (pp. 48-63). Schneiderverlag Hohengehren.

Radke, S., \& Tiemann, H. (2014). Inklusion-Umgangmit Vielfaltunterbesonderer Berücksichtigung der Kategorie Behinderung. In Diversität, Inklusion, Interkulturalität, \& Leitbegriffe der Politik, sportwissenschaftlicheDiskurse und Empfehlungfür den DOSB/dsj (pp. 14-20). Deutsche Sportjugend.

Reich, K. (2012). Inklusion und Bildungsgerechtigkeit. Standards und Regeln zur Umsetzung einer inklusiven Schule. Beltz Verlag.

Saldana, J. (2016). The Coding Manual for Qualitative Researchers. Sage Publications Inc.

Teubert, H. (2009). Koordination von Spitzensport und Schule: zur Lösung des Inklusionsproblems schulpflichtiger Athleten. Schneider-Verl. Hohengehren.

Thiele, J. (2005). Ethnographische Perspektiven der Sportwissenschaft in DeutschlandStaturs Quo und Entwicklungschancen (37 Absätze). Forum Qualitative Sozialforschung, 4, 257-279. https://www.ssoar.info/ssoar/handle/document/3056

Tiemann, H. (2013). Inklusiver Sportunterricht: Ansätze und Modelle. Sportpädagogik, $37,47-50$.

Tiemann, H. (2015a). Einen "Klassiker" aus neuer Perspektive entdecken—Brennball, ein Spiel für alle. In M. Giese, \& L. Weigelt (Eds.), Inklusiver Sportunterricht in Theorie und Praxis (pp. 118-124). Meyer und Meyer.

Tiemann, H. (2015b). Inklusiven Sportunterricht gestalten-Didaktisch-methodische Überlegungen. In M. Giese, \& L. Weigelt (Eds.), Inklusiver Sportunterricht in Theorie und Praxis (pp. 53-66). Meyer und Meyer.

Tiemann, H. (2016). Konzepte, Modelle und Strategien für den inklusiven Sportunterricht-Internationale und nationale Entwicklungen und Zusammenhänge. Zeitschrift für Inklusion.

https://www.inklusion-online.net/index.php/inklusion-online/article/view/382

United Nations (2006). Convention on the Rights of Persons with Disabilities and Optional Protocol. http://www.un.org/disabilities/documents/convention/convoptprot-e.pdf

Wenning, N. (2007). Heterogenität als Dilemma für Bildungseinrichtungen. In S. Boller, E. Rosowski, \& T. Stroot (Eds.), Heterogenität in Schule und Unterricht (pp. 32-41). Beltz. 